\title{
The Moderating Effect Of Regional Indpendence On The Effect Of Financing Policies, Capital Expenditure And Transfer Fund Towards The Performance Of Local Governments
}

\author{
Niko Silitonga $^{\mathrm{a}}$, Adler HaymansManurung ${ }^{\mathrm{b}}$ SekarMayangsari $^{\mathrm{c}}$, PartogianSormin $^{\mathrm{d}}$ \\ ${ }^{a}$ IKPIA Perbanas, Jakarta - Indonesia \\ ${ }^{\mathrm{b}}$ UniversitasBayangkara Jakarta Raya - Indonesia \\ ${ }^{c}$ UniversitasTrisakti, Jakarta - Indonesia \\ ${ }^{\mathrm{d}}$ UniversitasPelitaHarapan, Tangerang - Indonesia
}

Article History: Received: 10 November 2020; Revised 12 January 2021 Accepted: 27 January 2021; Published online: 5 April 2021

\begin{abstract}
The performance of local governments is one of the measuring tools in assessing whether the government has carried out the mandate given by the community to manage their regions properly and measurably. This study purpose to determine the effect of financing policies, capital expenditures and transfer funds on the performance of local governments with regional independence as a moderating variable in the provincial government in Indonesia. This study uses a quantitative research model using secondary data. The data in this study were processed using the Moderating Regression Analysis (MRA) method supported by the IBM SPSS and Microsoft Excel programs as support software with data analysis techniques in the form of classical assumption tests as well as R2 test, F test, and t test. The population in this study are provinces that have consistently published annual local government financial reports during 2014-201. This study used purposive sampling technique and obtained samples of 33 provinces according to predetermined criteria. The results of this study indicate that the financing policy proxied by net revenue has no effect on local government performance, while capital expenditure and transfer funds have a significant negative effect on local government performance, regional independence strengthens the relationship between capital expenditure and transfer funds to local government performance, meanwhile regional independence does not have a moderating role between the relationship between financing policies and local government performance. This study uses data from provinces in Indonesia, it is suggested that further research should add district / city level local governments with an extended period of time
\end{abstract}

Keywords: Net Regional Incomes, Capital Expenditures, Transfer Funds, Routine Capability Index, Human Development Index

\section{Introduction}

The management of the area of an area along with existing resources is very vital in the operation of the regional government, especially with the rolling out of the implementation of regional autonomy based on Law No. 32 of 2004 on Regional Government and Law no. 33 of 2004 on the financial balance between the central government and local governments.

Local governments are required to be able to run their government optimally in order to achieve regional independence, this is one of the benchmarks for assessing the performance of local governments both quantitatively in financial performance and qualitatively in the welfare of the people in their area. One of the indicators of community welfare that is often used as a reference is the human development index (HDI) which explains how a group of residents in an area can access development outcomes in the form of a decent standard of living, health and education.

The three indicators in the human development index (HDI) was very important because they can describe the quality of life of the people living in that area. The HDI score is closely related to the condition of the human resources of a region, the higher the HDI score in an area shows the higher the quality of human resources in that area, on the other hand, a low HDI score also indicates the low quality of human resources in that area. Meanwhile, human resources have an important role in determining the progress or withdrawal of an area at both the regional and state levels in addition to other factors (Todaro, 2000).

Focusing on information on data from the Central Bureau of Statistics (BPS) which shows the trend and growth of HDI in 2010-2016, there have been positive developments for human development in the country of Indonesia every year. Where the Human Development Index (HDI) in Indonesia in 2016 has reached 70.18 or an increase of 0.63 points compared to the previous year. This situation shows that Indonesia's HDI increased by 
$0.91 \%$ in the $2015-2016$ period. And in a period of five years the HDI growth was 3.65 points, meaning that human development in Indonesia in general is experiencing better development.

According to Sudarsana and Sri (2017: 63) stated that large capital expenditures are a reflection of the large number of infrastructure and facilities built. So that the more development carried out will improve services to the community so that regional performance will be better. Capital expenditures are expenditures for the payment of acquired assets and / or add to the value of fixed assets / other assets that provide benefits for more than one accounting period and exceed the minimum capitalization limit for fixed assets / other assets set by the government (Djuniar and Zuraida, 2018).

One of the policy breakthroughs made in the context of accelerating and equitable development in the regions, namely by giving part of the authority and power to local governments from the central government to manage and form new autonomous regions known as the implementation of decentralization. Along with the progress of the reform and decentralization process that provides flexibility for regions to maximize all existing regional potential, it is hoped that the progress of the development process in the regions and the acceleration of community welfare can be realized optimally, this situation will be seen by the government's ability to optimize the improvement of the quality of life of local communities and the quality. orderly and responsible government administration.

In other words, it can be said that the better the decentralization process in each area of operation, the better the performance of the government, which can be measured, among others, by increasing the Human Development Index (HDI) in the regions. This study will examine the decentralization factor in Indonesia which is proxied by the regional financial capacity (routine capability index) in influencing government performance.

\section{Theoritical Framework}

The theory used in this research is agency theory proposed by Jensen and Meckling (1976). The theoretical thinking is that there is a separation between ownership and control of the company. This study uses agency theory with the consideration that (1) the government as the manager or management of a government organization has the authority to manage all the potential and resources contained in the territory of its government to generate optimal income (2) The people as the owner and mandate of government have the authority to get welfare for the management carried out by management (government) as the recipient of the management mandate of government organizations.

In this condition, the owner, in this case the community will realize that the government tends to create policies that are contrary to their best wishes in an effort to maximize their interests as an owner as well as a management mandate, in certain positions the government sometimes also acts to think about its personal interests and / or importance of subjectivity too.

Existing financing receipts can be in the form of proceeds from the sale of separated regional assets, domestic loans, and from receiving back loans that have been given by the regional government to other parties. If the post of receipt of financing increases, it will be able to cover the existing APBD deficit. So that if the APBD deficit is covered by the receipt of financing, it will return a surplus. Meanwhile, financing expenditures can be in the form of reserve funds, local government equity participation, domestic loan principal payments, and loan provision to other parties. The difference between financing receipts and financing expenditures is net financing (Simamora, 2014).

Based on Law no. 33 of 2004, capital expenditures are expenditures used for the purchase or procurement of tangible fixed assets and have benefits for more than 12 months. Education spending has an influence on educational outcomes (Hidayat et al. 2012). Meanwhile, the education budget allocation, health budget, and people's purchasing power have a positive effect on the human development index (Kahang et al., 2016).

Antari, N (2018) argues that the high capital expenditure causes higher economic productivity, in this case the regional financial performance. Likewise, as stated by Andirfa, M (2016), which states that there is an effect of capital expenditure, balancing funds and PAD on the financial performance of local governments. (Ririn, et. Al., 2014) revealed that there is an effect of capital expenditure, investment and gross regional domestic product on local revenue.

(Suhiyanto, et.al, 2020) revealed that transfer funds (DAU, DBH, DAK and other legal income), PAD and Village Funds affect the human development index. The regional revenues that have the most influence on the HDI are the General Allocation Fund, the Regional Original Revenue or PAD and the Special Allocation Fund or DAK. This can be seen from the elasticity value or the total effect of each regional income. 
Sarwono (2012) shows that other legal revenues and general allocation funds (DAU) have a significant effect on regional spending. Gunantara (2014) revealed that PAD and DAU have a partially significant effect on Economic Growth, while capital expenditure has a partially negative and significant effect.

According to Hukom (2015), The regression analysis with panel data to analyze the effects of capital spending, economic growth and poverty on the Human Development Index in Central Kalimantan during 2006-2013 shows that capital expenditures issued by local governments have a significant positive effect on the Development Index. Human. This means that the greater the capital expenditure issued, will increase the Human Development Index.

The research framework used as a model for this research are:

Financing Policies, Capital Expenditures, Transfer Funds, Routine Capability Index, Human Development Index

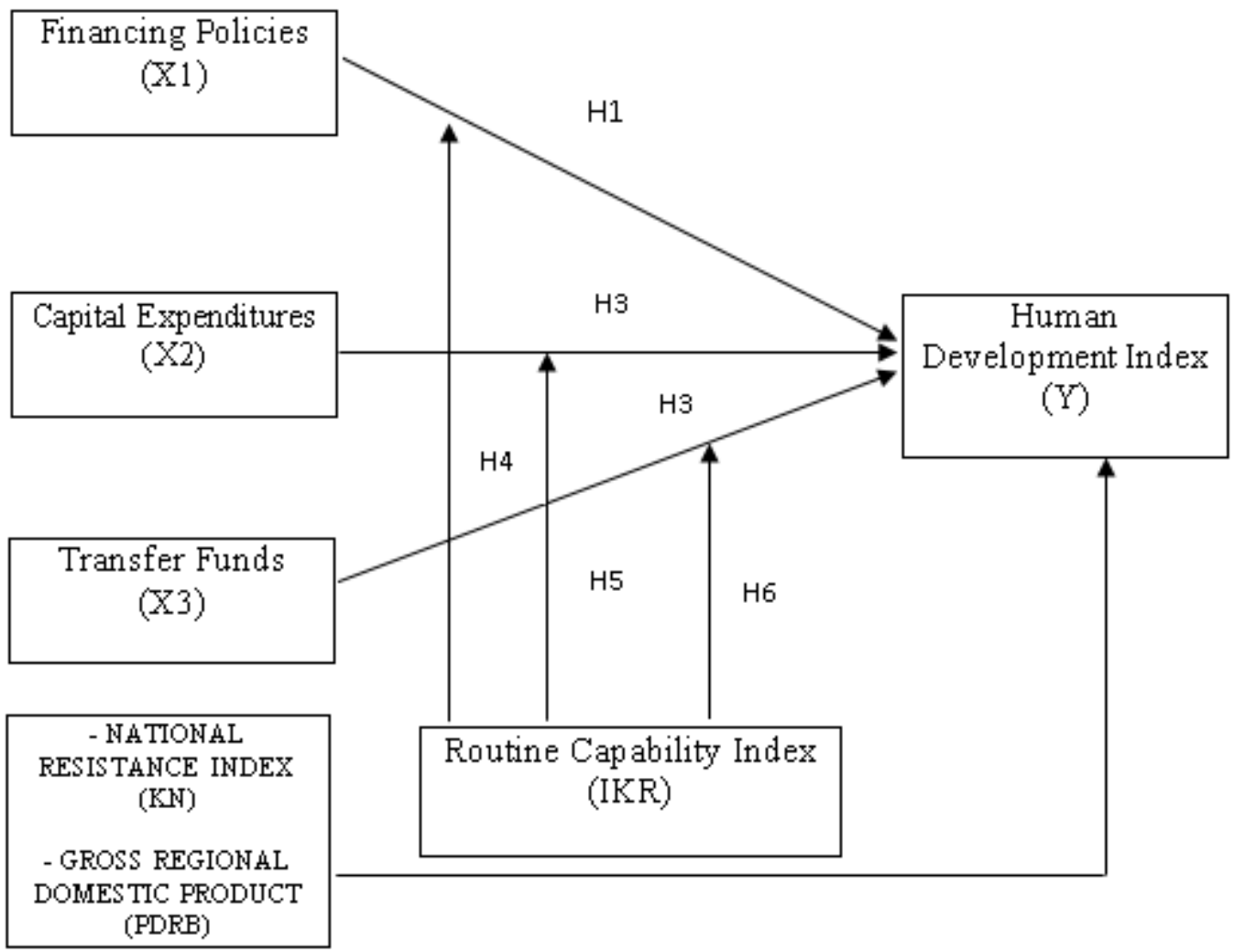

Figure 1. Conceptual Framework

\section{Development of Research Hypothesis}

\section{The Efffect of Financing Policies on Local Government Performance}

In the Regulation of the Minister of Home Affairs of the Republic of Indonesia No. 13 of 2006 concerning guidelines for regional financial management, regional financing consists of; (a) regional revenue consisting of the remaining profit from last year's budget calculation (SILPA), disbursement of funds, regional loan receipts, regional loan receipts, regional receivables receivables, and proceeds from the sale of separated regional assets. (b) Financing expenditures consisting of the formation of a reserve fund, equity participation, payment of principal debt, and provision of regional loans.

Meanwhile, Simamora, Sihar (2015) show that theoretically the remaining excess of budget calculations, revenues and financing expenditures has an effect on total expenditure in the future. However, there is a negative influence between the remaining budgetary costs on local government performance (Djuniar, Liz; Zuraida, Ida, 2018). Based on basic theoretical information in law and several studies obtained, a hypothesis is formulated:

\section{Ha1: Financing Policies affect the Local Government Performancre}

The Efffect of Capital Expenditures on Local Government Performance 
Nugroho's research (2016) reveals that in the group of regions with high HDI numbers, it is seen that health and infrastructure expenditures have a positive and significant effect on HDI through economic growth, whereas in the regional group with low HDI numbers, it can be seen that only education expenditure has a positive and significant impact. Significant to the HDI figures. As for economic growth, it seems that it shows a positive and significant effect on HDI. This occurred in both regional groups, both the regions with high HDI and low HDI.

In other research, Pramartha (2018) states that capital expenditure has no effect on the human development index, so that from some contradictory research results and based on theories related to capital spending seen in the rules and laws that govern it, the hypothesis proposed by the researchers is:

\section{Ha2: Capital Expenditure affect the Local Government Performancre}

\section{The Effect of Transfer Funds on Local Government Performance}

Based on "Republic Indonesia of Law no. 17 of 2003, concerning State Finances ", the Central Government will transfer the balance funds consisting of the General Allocation Fund (DAU), the Special Allocation Fund (DAK), and the Profit Sharing Fund to local governments to support the implementation of their authority in the regions, the policies of which are submitted. to the local government itself effectively and efficiently in improving services to the community in the area. UU no. 33 of 2004 states that the Special Allocation Fund (DAK) is a fund sourced from APBN revenues allocated to certain regions with the aim of helping to fund special activities which are regional affairs and in accordance with national priorities. The government determines DAK criteria which include general criteria, special criteria, and technical criteria. DAK recipient regions are required to provide Matching Funds of at least $10 \%$ (ten percent) of the DAK allocation. The Special Allocation Fund has a significant positive effect on capital expenditure (Novriansa, A and Subeki, A; 2014), while the results of research (Samau, et, al; 2016) show that the General Allocation Fund has a positive effect on personnel expenditure and capital expenditure. On the basis of theoretical explanations in the rules and regulations as well as the phenomena of the results of previous research, then the hypothesis is determined:

\section{Ha3: Transfer Funds affect Local Government Performance}

The Effect of Regional Independence as a moderator of the influence of Financing Policy on Local Government Performance

An autonomous region must have the authority and ability to seek its own financial resources, manage it and use its own finances which are sufficient to finance the running of its regional government. This is the main characteristic of being able to be autonomous (Sijabat, Saleh and Wachid 2013). Hardiyani, E Marisca and Haryadi (2016) show that the degree of decentralization / fiscal autonomy and the harmony of direct spending have a positive and significant effect on the human development index. This is also what the spirit of decentralization / regional autonomy has in common as reflected in Law no. 32 of 2004 which defines decentralization / regional autonomy as the right, authority and obligation of the autonomous region to regulate and manage government affairs and the interests of the local community in accordance with statutory regulations. With the explanation of the theory and previous research, the hypothesis was determined:

Ha4: Regional Independence Strengthens the Influence of Financing Policies on Local Government Performance

The Influence of Regional Independence as a moderating effect on Capital Expenditures on Regional Government Performance

Autonomous regions have broad, real and responsible autonomy. Then regional autonomy is implemented while still paying attention to the diversity of existing regions and the principles of democracy that are adjusted to local wisdom in the area, then management in the form of regulation, distribution and empowerment of all national potentials is implemented based on the principle of justice while still paying attention to the balance of central and regional financial factors. proportionally. Setyawan, M Rudy and Arief, Sjamsul (2019) stated that Fiscal Decentralization, Economic Growth and Capital Spending have a significant positive effect on the human development index in 9 cities in East Java province. (Harliyani, EM and Hariadi; 2016) revealed that the ratio of the degree of fiscal decentralization has a significant effect on the human development index. Based on the theoretical explanation and several previous studies, the following hypothesis was established:

\section{Ha5: Regional Independence Strengthens the Influence of Capital Expenditures on Local Government Performance}

\section{The Influence of Regional Independence as a moderator of the influence of Transfer Funds on Regional} Government Performance

Law No. 32 of 2004 which defines decentralization / regional autonomy as the right, authority and obligation of the autonomous region to regulate and manage government affairs and the interests of the local community in 
accordance with statutory regulations. The General Allocation Fund has a significant effect on Regional Expenditures. This proves that the size of the General Allocation Fund revenue has an effect on Regional Expenditures. The Special Allocation has no significant effect on Regional Expenditures. This proves that the size or size of the Special Allocation Fund receipts has no significant effect on Regional Expenditures. Profit Sharing Fund has no significant effect on Regional Expenditures. This proves that the size or size of revenue sharing funds has no significant effect on regional expenditure (Fatimah, et, al; 2019). With the explanation of the theory and previous research, the following hypotheses were established:

\section{Ha6: Regional Independence Strengthens the Effect of Transfer Funds on Local Government Performance}

\section{Research Methodology}

This study uses a quantitative research model using secondary data. The data in this study were processed using the Moderating Regression Analysis (MRA) method supported by the IBM SPSS and Microsoft Excel programs as support software with data analysis techniques in the form of classical assumption tests as well as R2 test, $\mathrm{F}$ test, and $\mathrm{t}$ test. The population in this study are provinces that have consistently published annual local government financial reports during the 2014-2018 period. This study used purposive sampling technique and obtained samples of 33 provinces according to predetermined criteria. PersamaanRegresi Model Penelitianiniadalahsebagaiberikut:

$$
\begin{aligned}
\mathrm{Y}= & \alpha+\beta 1 \mathrm{PN}+\beta 2 \mathrm{BM}+\beta 3 \mathrm{DT}+\beta 4 \mathrm{PN} * \mathrm{IKR}+\beta 5 \mathrm{BM} * \mathrm{IKR}+\beta 6 \mathrm{DT} * \mathrm{IKR}+\beta 7 \mathrm{IKN} \\
& +\beta 8 \mathrm{PDRB}+\mathrm{e}
\end{aligned}
$$

Keterangan:

Y

PN : Netto Revenues

BM : Capital Expenditure

DT : Transfer Fund

IKR : Routine Ability Index

IKN : National Resistance Index

PDRB : Gross Regional Domestic Product

$\alpha \quad$ : Constant

$\beta \quad$ : Regression Coefficient

e : Standar Error

Operational variables and measurements used are as follows:

\begin{tabular}{|c|c|c|c|}
\hline $\mathrm{N}$ & Variable (Proxy) & $\mathrm{e}^{\text {Scal }}$ & Measurement \\
\hline 1 & $\begin{array}{l}\text { Independent } \\
\text { Variable } \\
\text { Netto Revenues }\end{array}$ & Rati & $\begin{array}{l}\Delta \mathrm{PN}=\quad \text { PNyear } \mathrm{t}-\text { PNyear }(\mathrm{t}-1) . \\
\text { (Permendagri No. } 13 \text { year, 2006) }\end{array}$ \\
\hline 2 & $\begin{array}{l}\text { Independent } \\
\text { Variable } \\
\text { Capital } \\
\text { Expenditures }\end{array}$ & Rati & $\begin{array}{l}\text { Capital Expenditures year, t-1 } \\
\text { (Permendagri No. } 13 \text { yaer, 2006) }\end{array}$ \\
\hline 3 & $\begin{array}{l}\text { Independent } \\
\text { Variable }\end{array}$ & Rasi & $\Delta$ Transfer Funds $=\quad$ DTyear $\mathrm{t}-$ DTyear $(\mathrm{t}-1)$ \\
\hline
\end{tabular}

Table 1. Operational Variables and Measurements 


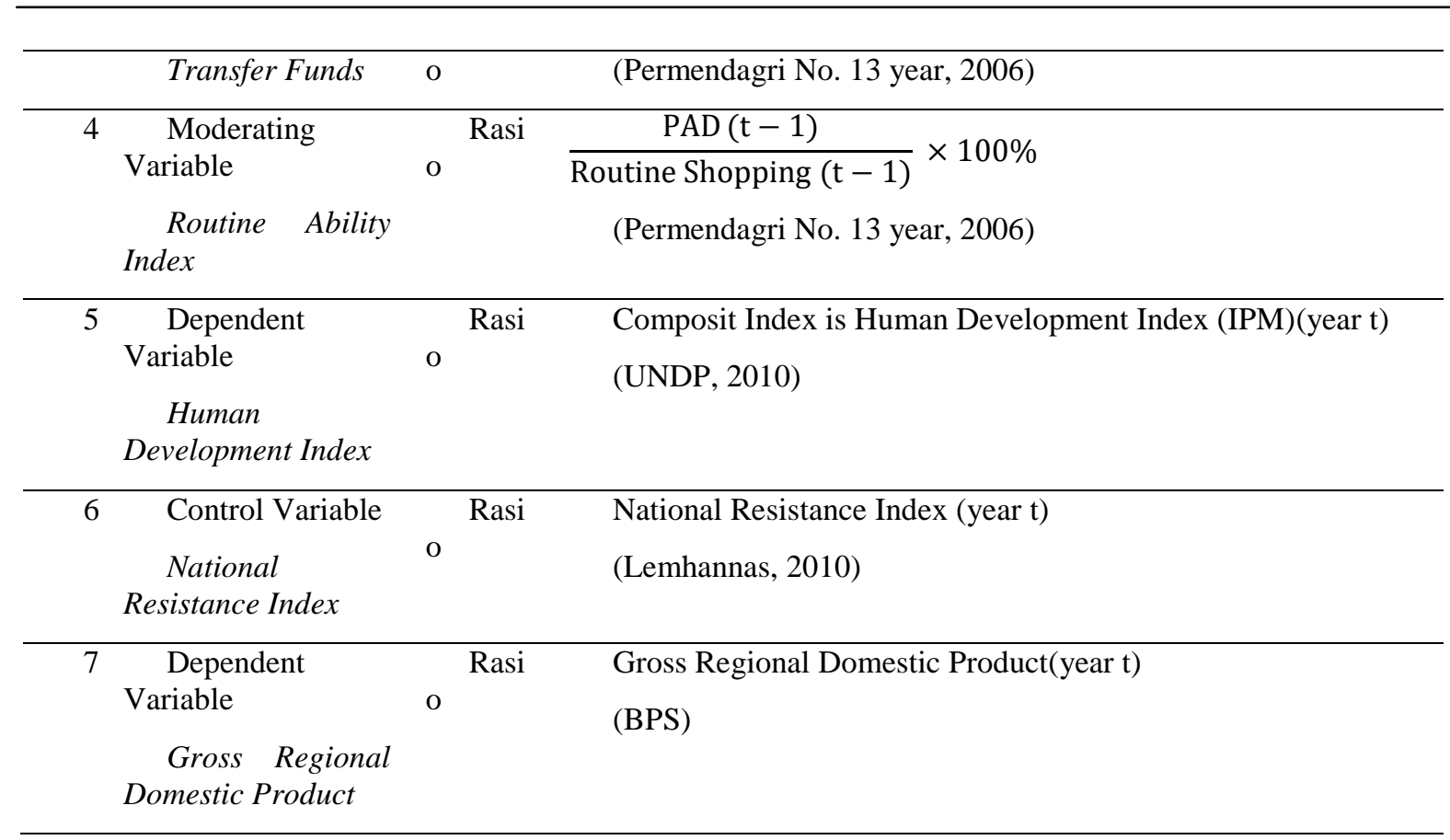

Source: Data processed by researchers (2021)

\section{Finding, Data Analysis And Discussions}

The sample selection criteria used in the sample selection technique were purposive sampling based on predetermined criteria. From this selection, 33 provinces that met the criteria during the 4-year data observation period were obtained, of the 34 provinces that became the population. Summary The results of the sample selection of this study are as follows:

Table 2. Summary of Sample Selection and Number of Observations

\begin{tabular}{|l|l|}
\hline Description & Number of Provinces \\
\hline $\begin{array}{c}\text { The number of provinces registered with the Indonesian Ministry } \\
\text { of Home Affairs in 2018 }\end{array}$ & 34 \\
\hline $\begin{array}{c}\text { Provinces that do not have complete APBD Realization Reports } \\
\text { for the period of December 31th, 2015 to December 31th, 2018 }\end{array}$ & $(1)$ \\
\hline $\begin{array}{c}\text { Provinces that do not have periodic BPK audit reports December } \\
\text { 31th, 2015to December 31th, 2018 }\end{array}$ & 0 \\
\hline Total samples per year & 33 \\
\hline Observation Period (years) & 4 \\
\hline The Sum of Observations & 132 \\
\hline
\end{tabular}

Resources: Secondary data from the Ministry of Home Affairs were processed by researchers

Based on the data in table 2 above, it shows that the number of data in the study (N) is 132 observations used as a unit of data analysis based on sample criteria (purposive sampling), consisting of 33 provinces with a period of 4 years (2015-2018).

Tabel 3. Descriptive statistics

\begin{tabular}{|c|c|c|c|c|c|}
\hline & & Minimu & Maximu & & \\
\hline & $\mathrm{N}$ & $\mathrm{m}$ & $\mathrm{m}$ & Mean & Std. Deviation \\
\hline IPM & 132 & 57.25 & 80.47 & 69.4651 & 4.16783 \\
\hline $\mathrm{PN}$ & 132 & -12.55 & 13.02 & -1.4936 & 11.05287 \\
\hline $\mathrm{BM}$ & 132 & 10.28 & 13.04 & 11.9500 & .36840 \\
\hline DT & 132 & -12.83 & 12.97 & 6.3295 & 9.75257 \\
\hline IKR & 132 & 8.88 & 141.38 & 60.8012 & 29.82648 \\
\hline
\end{tabular}




\begin{tabular}{llllll} 
IKN & 132 & 2.00 & 3.00 & 2.9394 & .23952 \\
PDRB & 132 & -556.00 & 2020.00 & 376.4545 & 261.15259 \\
\hline Valid N & 132 & & &
\end{tabular}

\section{Source: Data processed by researchers}

Based on the data in Table 3, it can be seen that the human development index variable (IPM_Y) has a standard deviation value of 4.168 with an average value of 69.465 , the highest value is 80.47 and the lowest value is 57.25 . This shows that the variability sample province's human development index tends not to be too high in each province, only in certain provinces where the difference is relatively large with certain provinces. The province with the highest human development index was DKI Jakarta in 2018 and the lowest was Papua in 2015.

Net financing has a relatively small mean value compared to the standard deviation value. This shows that the variability of financing policies from each province is quite high, so that it is far from the mean value. The net financing variable (PN_X1) has a standard deviation value of 11.05287 with a mean value of -1.4936 , while the highest value is 13.02 and the lowest is -12.55 . This shows that the financing policies of the sample provinces have fluctuating and varied net financing.

Capital expenditure has a standard deviation value smaller than the mean value, this shows that the variability of capital expenditure from each province is relatively not too high in each province. The capital expenditure variable (BM_X2) has a standard deviation value of 0.36840 with a mean value of 11,950 , while the highest value is 13.04 and the lowest is 10.28 . This shows that the capital expenditures for the sample provinces are relatively modest.

The mean value of transfer funds is also relatively small compared to the value of its standard deviation. The transfer funds variable (DT_X3) has a standard deviation value of 9.75257 with a mean value of 6.3295 , while the highest value is 12.97 and the lowest value is -12.83 . This shows that the sample provincial transfer funds received from several sources fluctuate depending on the ability of local government management and central government policies on the basis of an analysis of revenue and the adequacy of funds for all other provinces.

For control variables, the national resilience index (IKN) and gross regional domestic product (GRDP) have a mean value greater than the standard deviation value. The variable of national resilience (IKN) has a standard deviation value of 0.2395 with a mean value of 2.9394 with the highest value of 3 and the lowest value of 2.The gross regional domestic product (GRDP) variable has a standard deviation value of 261.1526 with a mean value of 376,4545 with the highest value of 20.20 and the lowest value of $-556 ., 0$ The mean value exceeding the standard deviation means that the national resilience index (IKN) and gross regional domestic product (GRDP) can be used as a representation of the control variable.

The decentralization variable as measured by the routine ability index (IKR) has a standard deviation value of 29.82648 with a mean value of 60.8012 with the highest value of 141.38 and the lowest value of 8.88 . This indicates that decentralization as measured by the routine ability index is indeed running between provinces that optimally take advantage of regional autonomy and provinces that do not optimally take advantage of regional autonomy.

Table 4. The Effect of Financing Policy, Capital Expenditure and Fund Transfers to local government performance to the Regional Independence as moderating

\begin{tabular}{|c|c|c|c|c|}
\hline \multicolumn{5}{|c|}{$\begin{array}{l}\text { Model: } \\
\begin{aligned} \mathrm{IPM} & =\beta 0+\beta 1 \mathrm{PN}+\beta 2 \mathrm{BM}+\beta 3 \mathrm{DT}+\beta 4 \mathrm{PN} * \mathrm{IKR}+\beta 5 \mathrm{BM} * \mathrm{IKR}+\beta 6 \mathrm{DT} * \mathrm{IKR}+\beta 7 \mathrm{IKN} \\
& +\beta 8 \mathrm{PDRB}+\mathrm{e}\end{aligned}\end{array}$} \\
\hline & $\mathrm{n}$ Predictio & $\begin{array}{ll} & \text { Coefficient }\end{array}$ & T-stat & Significant \\
\hline Cons & & 104.891 & 4.500 & .000 \\
\hline $\mathrm{PN}$ & + & -.029 & -.482 & .631 \\
\hline$\overline{B M}$ & + & -3.890 & -2.105 & $.037 * *$ \\
\hline
\end{tabular}




\begin{tabular}{|l|c|c|c|c|}
\hline DT & + & -.161 & -2.191 & $.030^{* *}$ \\
\hline IKR & + & -.784 & -2.485 & $.014 * * *$ \\
\hline PN*IKR & + & .000 & .441 & .660 \\
\hline BM*IKR & + & .070 & 2.677 & $.008^{* * *}$ \\
\hline DT*IKR & + & .002 & 1.716 & $.089 *$ \\
\hline IKN & + & 3.104 & 2.414 & $.017 * *$ \\
\hline PDRB & + & -.003 & -2.289 & $.024 * *$ \\
\hline R Square & 0.455 & & \\
Adjusted R2 & 0.414 & \\
F-Statistic & 11.303 & \\
Prob (F-Statistic) & $0.009^{* * *}$ \\
Number of Observation & 132 & \\
\end{tabular}

\begin{tabular}{|c|c|}
\hline $\begin{array}{ccc}\text { Dependent } & \text { Variable: } & \text { Human } \\
\text { Development Index }(\mathrm{HDI}) & \end{array}$ & $\begin{array}{l}\text { Independent Variable: } \\
\text { 1. PN: PenerimaanNeto } \\
\text { 2. BM: Belanja Modal } \\
\text { 3. DT: Dana Transfer }\end{array}$ \\
\hline $\begin{array}{l}\text { ***Significant at a level of } 1 \text { percent; } \\
* * \text { Significant at a level of } 5 \text { percent; } \\
\text { *Significant at a level of } 10 \text { percent }\end{array}$ & $\begin{array}{l}\text { Moderating Variable: } \\
\text { 1. IKR: IndeksKemampuanRutin } \\
\text { Control variable: } \\
\text { 1. IKN: IdeksKetahananNasional } \\
\text { 2. } \quad \text { PDRB: ProdukDomestik regional Bruto }\end{array}$ \\
\hline
\end{tabular}

Source: Data processed by researchers

Based on table 4, the regression model is formulated as follows:

\section{IPM = 104,891 - 0,029 PN - 3,890 BM - 0,161 DT - 784 IKR + 0,000 PN*IKR + 0,070 BM*IKR + 0,002 DT*IKR + 3,104 IKN - 0,003 PDRB + \&}

With an adjusted R2 value of 0.414 , it indicates that Net Revenues, Capital Expenditures and Funds Transfer are able to explain the effect of $41.4 \%$ on the human development index. Meanwhile, the value of $\mathrm{F}$ test 11.303 with a significance value of 0.000 indicates that the proposed model with the research variables used is feasible to be used as a model in this study.

Based on table 4 above, the summary of the results of the regression model for this study is explained as follows:

1. The results of the regression test for the first hypothesis (H1) show that Net Revenue (PN) with a significance value of 0.631 has no effect on government performance as measured by the Human Development Index (HDI). Refers to the maximum normal significance level of 10\% (Hair, 2014).

2. The results of the second hypothesis regression test $(\mathrm{H} 2)$ show that capital expenditure (BM) has a negative effect on government performance as measured by the Human Development Index (HDI) with a significance value of 0.037 referring to the maximum normal significance level of $10 \%$ (Hair, 2014).

3. The results of the third hypothesis regression test (H3) show that Fund Transfer (DT) has a negative effect on government performance as measured by the Human Development Index (HDI) with a significance value of 0.030 referring to the maximum normal significance level of $10 \%$ (Hair, 2014). 
4. The results of the fourth hypothesis regression test (H4) show that the interaction of the Routine Capability Index (IKR) and Net Revenue (PN) with a significance value of 0.660 is not able to moderate the effect of Net Revenue on government performance as measured by the Human Development Index (HDI). Refers to the maximum normal significance level of $10 \%$ (Hair, 2014).

5. The results of the fifth hypothesis regression test (H5) show that the interaction between the Routine Capability Index (IKR) and Capital Expenditure (BM) is able to strengthen the effect of Capital Expenditures (BM) on government performance as measured by the Human Development Index (HDI) with a coefficient of 0.070 and The significance value of 0.008 refers to the maximum normal significance level of $10 \%$ (Hair, 2014).

6. The results of the sixth hypothesis regression test (H6) show that the interaction between the Routine Capability Index (IKR) and Transfer Funds (DT) is able to strengthen the effect of Transfer Funds (DT) on government performance as measured by the Human Development Index (HDI) with a coefficient of 0.002 and The significance value of 0.089 refers to the maximum normal significance level of $10 \%$ (Hair, 2014).

\section{Discussion Of Findings}

In this study, it was found that the net income has no effect on government performance as measured by the human development index, these results indicate that the revenue and expenditure financing policies taken by the government do not have a direct impact on the welfare that is felt directly by the community but rather have a role in the political and financial aspects. and local government budgets alone, the results of this study are not in line with what was stated (Aggarwal, et al, 2003) that investment has a positive influence on company performance.

In this research, it was found that capital expenditure has a negative and significant effect on government performance as measured by the human development index, this result shows that a decrease in capital spending will have an impact on optimizing the use of government budget funds to increase other productive things for the welfare of the community such as for the purposes of education, health and other social services that are reflected in the human development index in the blood, this result is in line with the research of Setyawan, M Rudy and Arief, Sjamsul (2019) which states that Fiscal Decentralization, Economic Growth and Capital Spending have a significant positive effect on the index. human development in 9 cities in East Java province.

In this study, it was also found that the results of transfer funds have a negative and significant effect on government performance as measured by the human development index, these results indicate that any reduction in transfer funds will have an impact on the performance of local governments through optimizing local government financing from the pure results of regional resource management, among others. Original regional income, and the use of budget allocations are more directed towards programs to increase other productive things for the welfare of the community, such as for the needs of education, health and other social services as reflected in the human development index in the blood, this result is in line with the research. Gunantara (2014) who states that the General Allocation Fund (DAU) has a significant effect on partial economic growth, it is different from the results of research conducted by Purpitasari (2015) which states that DAU has an effect on defense. nja area but insignificant. Both studies state that DAU as an instrument for receiving funds from the central government or Level 1 local government has an impact on program implementation and government performance.

In this study, it was found that the interaction between routine ability index and net income had no effect on government performance as measured by the human development index. These results indicate that the revenue and expenditure financing policies taken by the government in the context of regional independence do not have a direct impact on the welfare that is felt directly. by the community but plays a greater role in the political, financial and regional government budget aspects, in other words, transfer funds are only able to increase regional independence but have not been able to raise the welfare of the community, this is in line with the research results of Muana, Nanga and Runtuk, J Krisnanto (2020). which indicates that the General Allocation Fund and the Revenue Sharing Fund have a significant effect on the level of regional independence.

In this study, it was found that the interaction between routine capability index and capital expenditure has a positive and significant effect on government performance, this result shows that regional independence is able to strengthen the effect of capital expenditure on local government performance as measured by the human development index, meaning that every one unit of regional independence interaction value with capital spending will increase the human development index by 0.0070 unit value, this result is in line with the research of Setyawan, M Rudy and Arief, Sjamsul (2019) which states that Fiscal Decentralization, Economic Growth and Capital Spending have a significant positive effect on the human development index in 9 cities in the province of East Java. Likewise, in line with Nurhidayati's research results, Sri (2017) states that the degree of fiscal decentralization has a significant positive effect on local government performance as measured by the opinion of regional government financial statements. 
In this study, it was found that the interaction between routine capability index and Transfer Funds has a significant positive effect on government performance, this result shows that regional independence is able to strengthen the effect of transfer funds on local government performance as measured by the human development index, meaning that each unit value of transfer funds is in the context of implementation of regional independence will increase the human development index by 0.002 unit value, this result is in line with the research of Setyawan, M Rudy and Arief, Sjamsul (2019) which states that Fiscal Decentralization, Economic Growth and Capital Expenditures have a significant positive effect on the human development index. Likewise, Nurhidayati's research results, Sri (2017) stated that the degree of fiscal decentralization has a significant positive effect on local government performance as measured by the opinion of the regional government financial statements.

\section{Conclusion AndRecomendation}

Based on the results of this study, it can be concluded that capital expenditure and transfer funds have a negative and significant impact on government performance as measured by the human development index, and at the same time regional independence is able to strengthen the effect of capital expenditure and transfer funds on local government performance. Thus, decentralization as a form of regional independence can be carried out optimally by the government to maximize services and increase the welfare of its people. However, net revenue as a measure of financing policy has no effect on government performance.

Based on the discussion and conclusions obtained, the implications of this study are: (1) For academics and researchers, to be able to develop other measurements that can be used in local government performance variables, such as the growth of PAD and Opni audit. (2) For the regional government, this research can provide input to the government to be able to choose and optimize the source of revenue of funds and the allocation of capital expenditures for productive things in order to move the community's economy and community participation in the development process. (3) This study only uses data from the provincial government for a period of 4 years, it is better if further research is possible to obtain complete data from the entire province of the entire population with a longer study period

\section{References}

Adi, PriyoHari (2007). "Hubunganantarapertumbuhanekonomidaerah, belanjapembangunandanpendapatanaslidaerah”. ProccedingSimposiumNasionalAkuntansi IX, Padang.

Aggarwal, R and AungKyaw, N. N, (2006), "Leverage, Investment Opprtunities, and Firm Value: A Global Perspective on the Influence of Financial Development", Kent State University, Kent, OH 44242.

Antari, Ni Putu Gina Sukma. 2018. PengaruhPendapatanAsli Daerah danBelanja Modal TerhadapKinerjaKeuanganPemerintah Daerah. E JurnalManagemen: UNUD Vol7 :1080-1110

Arnaboldi, M., Azzone, G. and Palermo, T. (2010), "Managerial innovations in central government: not wrong, but hard to explain”, International Journal of Public Sector Management, Vol. 23 No. 1, pp. 78-93.

Badjuri H. AbdulkahardanYuwono, Teguh. (2012). KebijakanPublijk: KonsepdanStrategi. FISIP UniversitasDiponegoro.

Bastian, Indra. (2006). AkuntansiSektorPublik: SuatuPengantar .Erlangga.

Drebin, A. (1980). "Criteria for Performance in State and Local Government”, Government Finance, pp. 9, 3-7

Fatimah, N. N., Nopiyanti, A., \&Mintoyuwono, D. 2019. PengaruhPendapatanAsli Daerah dan Dana PerimbanganterhadapBelanja Daerah. Equity, 22(2), 197-214.

Fenwick, John; and Miller, K Johnston, (2012) "Political management and local performance: a testing relationship?", International Journal of Public Sector Management, Vol. 25 Issue: 3, pp.221-230

Grubnic, S and Woods, M. (2009), "Hierarchical control and performance regimes in local government", International Journal of Public Sector Management, Vol. 22 Issue: 5, pp.445-455,

Gunantara, PutuCandra (2014). PengaruhPendapatanAsli Daerah dan Dana AlokasiUmumPadaPertumbuhanEkonomidenganBelanja Modal SebagaiVariabelPemoderasi di Bali. EJurnalAkuntansiUniversitasUdayana, 7.3, hal 529-546.

Halim, Abdul. (2008). AkuntansiKeuangan Daerah. EdisiRevisi 3. SalembaEmpat Jakarta.

Harliyani, EM danHariadi (2016), "PengaruhKinerjaKeuanganPemerintah Daerah TerhadapIndeks Pembangunan Manusia di Provinsi Jambi“, JurnalPerspektifPembiayaandan Pembangunan Daerah, Vol.3. No.3. (2016): 2338-4603

Harun, H. Hamrolie. (2004). AnalisisKetersediaan Dana Pembangunan Daerah. Edisi 1. BPFE Yogyakarta.

Hidayat, I., R. Rosidi, dan E. Saraswati. 2012. PengaruhBelanjaPendidikanTerhadapKinerjaPendidikandengan Good Governance sebagaiVariabelModerasi. JurnalAkuntansiMultiparadigma 3(2): 173-186. 
Hukom, Alexandra (2015), "Effect of Capital Expenditures, Economic Growth And Poverty On Human Development In Central Kalimantan", IOSR Journal of Economics and Finance (IOSR-JEF). Volume 6, Issue: 3, PP 19-27

Ismerdekaningsih, Herlina, SE danEndah Sri Rahayu, SE. 2002. "AnalisisHubunganPenerimaanPajakTerhadapProdukDomestikBruto di Indonesia (StudiTahun 1985-2000)". ITB Central Library.

Janssen,Marijn; Anton Joha; VishanthWeerakkody, (2007) "Exploring relationships of shared service arrangements in local government", Transforming Government: People, Process and Policy, Vol. 1 Issue: 3 , pp.271-284,

Jaya, I.P.N.P.K. dan A.A.N.B Dwirdanra, (2014), "PengaruhPendapatanAslidaerahpadaBelanja Modal denganPertumbuhanEkonomisebagaivariabelModerasi” : E- JurnalAkuntansiUniversitasUdayana 7. 1: 79 92.

KementerianDalamNegeriRepublik Indonesia. Data Realisasi APBD Tahun 2014.

KementerianDalamNegeriRepublik Indonesia. Data Realisasi APBD Tahun 2015.

KementerianDalamNegeriRepublik Indonesia. Data Realisasi APBD Tahun 2016.

KementerianDalamNegeriRepublik Indonesia. Data Realisasi APBD Tahun 2017.

KementerianDalamNegeriRepublik Indonesia. Data Realisasi APBD Tahun 2018.

Kahang, M., M. Saleh, dan R. B. Suharto. 2016. PengaruhPengeluaranPemerintahSektorPendidikandanKesehatanTerhadapIndeks Pembangunan Manu- sia di KabupatenKutaiTimur. JurnalEkonomi, ManajemendanAkuntansi 18(2): 130-140.

Kihn, L.-A. (2010), "Performance outcomes in empirical management accounting research: recent developments and implications for future research", International Journal of Productivity and Performance Management, Vol. 59 No. 5, pp. 468-92.

JurnalAkuntansidanKeuanganSektorPublik, Vol. 06 No. 02, hal. 39-55

Lemhannas RI, PokjaKetahananNasional, Buku 8 Modul 3 BS/MateriPokokKetahananNasional, Jakarta, 2016.

Mahmudi. (2016). AkuntansiSektorPublik .EdisiRevisi. Penerbit UII Press Yogyakarta.

Manurung, Adler H; danBudiastuti, Dyah. (2019). MetodeRiset: Akuntansi, Investasi, KeuangandanManajemen. EdisiPertama. Penerbit PT. Adler Manurung Press Jakarta.

Manurung, Adler H; danKartika, Tipri R. (2020), "Non-Performing Loan Moderated by Risk: Speed Adjustment and Gender". Phsychology and Education, Vol. 57(9): 2276-2285

Mardiasmo. (2002). OtonomidanManajemenKeuanganDaerah .EdisiPertama. PenerbitAndi Yogyakarta.

Mardiasmo. (2004). AkuntansiSektorPublik. Edisi 2. PenerbitAndi Yogyakarta.

Mardiasmo. (2009). AkuntansiSektorPublik. Edisi 4. PenerbitAndi Yogyakarta.

McLeod, R. (2005), "Private sector lessons for public sector reform in Indonesia", working paper, Australian National University, Canberra, 6 December.

Meier, K.J., O’Toole, L.J. Jr, Boyne, G.A. and Walker, R.M. (2006), "Strategic management and the performance of public organizations: testing venerable ideas against recent theories", Journal of Public Administration Research and Theory, Vol. 17, pp. 357-77.

Micheli, P. and Neely, A. (2010), "Performance measurement in the public sector in England: searching for the golden thread", Public Administration Review, Vol. 70 No. 4, pp. 591-600.

MuliaAndirfa. 2016. PengaruhBelanja Modal, Dana PerimbangandanPendapatanAsli Daerah TerhadapKinerjaKeuanganKabupatendan Kota Di Provinsi Aceh. Aceh: UniversitasSyiah Kuala Banda Aceh.

Nkechukwu1 G C and Okoh J I, (2013), "Capital Expenditure at Disaggregated level and Economic Growth in Nigeria: An Empirical Analysis”, International Journal of Science and Research (IJSR), pp. 729-737

Novriansa, A danSubeki,A; (2020), "Pengaruh Dana AlokasiKhusus, PendapatanAsli Daerah, danSisaLebihPembiayaanAnggaranterhadapBelanja Modal PemerintahKabupaten,Kota di Pulau Sumatera“, Akuntabilitas: JurnalPenelitiandanPengembanganAkuntansi Vol.8. No.2. Juli (2014): 145-158

Nugroho, Fajar; Rohman, Abdul (2012), "PengaruhBelanja Modal TerhadapPertumbuhanKinerjaKeuangan Daerah denganPendapatanAsli Daerah sebagaiVariabel Intervening", Diponegoro Journal of Accounting, Vol. 1 No: 2, Halaman 1-14

Nugroho, GA (2016) “AnalisisPengaruhPengeluranPemerintahTerhadapPertumbuhanEkonomidanIndeks Pembangunan Manusia di Indonesia”, Indonesian Treasury Review (JurnalPerbendaharaan, Keuangan Negara danKebijakanPublik), Vol.1, No.1, 2016, Hal. 39-50. 
$\begin{array}{llllll}\text { Pambelum, } & \text { Y Joni } & \text { NanAwat, } & \text { Napa }\end{array}$ "PengaruhSistemInsentifterhadapEfektivitasKinerjaDinasPendapatan Daerah Kota Palangkaraya", JurnalAkuntansidanKeuanganSektorPublik, Vol. 06 No. 01, hal. 130-155

PeraturanPemerintah No. 71 Tahun 2010 tentang Standard AkuntansiPemerintah..

PeraturanPemerintah No. 58 Tahun 2005, tentangPengelolaanKeuangan Daerah.

Permendagri No. 13 Tahun 2006, tentangPedomanPengelolaanKeuangan Daerah.

Permendagri No. 21 Tahun 2012, tentangPedomanPenyusunan APBD.

Pilcher, R. and Dean, G. (2009), "Consequences and costs of financial reporting compliance for local government", European Accounting Review, Vol. 18 No. 4, pp. 725-44.

Pilcher, Robyn (2005) "Local government financial key performance indicators - not so relevant, reliable and accountable", International Journal of Productivity and Performance Management, Vol. 54 Issue: 5/6, pp.451467

Pilcher, Robyn (2009), "Deconstructing local government performance and infrastructure measurement", Asian Review of Accounting, Vol. 17 Issue: 2, pp.163-176

Pramartha, IMA; Dwirandra AANB (2018), "PengaruhDesentralisasiFiskal, Belanja Modal, danInvestasiSwastaTerhadapIndeks Pembangunan Manusia “, E-JurnalAkuntansiUniversitasUdayana Vol.22.3. Maret (2018): 2458-2482

Purpitasari, Puput (2015). "PengaruhPendapatanAsli Daerah dan Dana AlokasiUmumTerhadapAlokasiBelanja Daerah". JurnalIlmu\&RisetAkuntansi,Vol. 4 No. 11, hal 1-16.

Ratmono, D; Sholihin, M. (2017). AkuntansiKeuangan Daerah BerbasisAkrual .EdisiKedua. UPP STIM YKPN.

Razmi, M Javad; AbbasianEzatollah; Mohammadi, Sahar (2012), "Investigating the Effect of Government Health Expenditure on HDI in Iran", Journal of knowledgment management, economics and information technology, issue 5, oct 2012

Renyowijoyo, Muindro. (2011). AkuntansiSektorPublik: Organisasi Non Laba .Edisi 2. MitraWacana Media.

Samau, N; Rumate, V; Londa, AT (2016), "AnalisisKontribusisertaPengaruh Dana AlokasiUmum (DAU) terhadapBelanja Daerah KabupatenKepulauanSangihe“, JurnalBerkalallmiah; Efisiensi Vol.16. No.2. (2014): 255-266

Sarwono, E (2012), "PengaruhPajak Daerah, Retribusi Daerah, PendapatanLainnya yang Sah, dan Dana AlokasiUmumTerhadapBelanja Daerah padaKabupaten/Kota Se Indonesia TahunAnggaran 2010-2011", eprints.dinus.ac.id .

Sekaran, U. (2013). Research Methods For Business: A Skill Building Approach. Six Edition, Wiley.

Setyawan, MR danArief, Syamsul. (2019) "PengaruhDesentralisasiFiskal, PertumbuhanEkonomisertaBelanja Modal terhadapIndeks Pembangunan Maanusia (studikhusus 9 kota di ProvinsiJawaTimur 2008-2017", JurnalEkonomidanBisnis, Vol.4, No. 2, Sept 2019), hal. 907-918.

Sijabat, M; Saleh, C; Wachid, A (2014), "AnalisisKinerjaKeuangansertaKemampuanKeuanganPemerintah Daerah dalamPelaksanaanOtonomi Daerah", JurnalAdministrasiPublik, Vol.2, No. 2, hal. 236-242.

Simamora, Sihar (2014). Pengaruhsisalebihperhitungananggaran $\quad$ (SILPA), penerimaandanpengeluaranpembiayaanterhadapbelanjadaerah; Jurnalrisetakuntansidanbisnis, vol 14 No. 2, september 2014, pp 21-37

Sudiyatno, B danPuspitasari, E (2010), "PengaruhKebijakan Perusahaan terhadapNilai Perusahaan denganKinerja Perusahaan sebagaiVariabel Intervening”, JurnalDinamikaKeuangandanPerbankan, Vol.2, hal. $1-22$.

Sugiyono (2013). MetodePenelitianKuantitatif. PenerbitAlfabeta, Bandung.

Suhartono, E dan Halim,

PengaruhPartisipasiPenyusunanAnggarandanKejelasanSasaranAnggaranterhadapKinerjaManajerialPemerinta h Daerah denganMotivasisebagaiVariabelPemoderasi, JurnalAkuntansidanKeuanganSektorPublik, Vol. 06 No. 01, hal. 01-26

Suhyanto, O; Juanda,B; Fauzy,A; Rustiadi,E (2020), "Pengaruh Dana Transfer, Dana Desadan PAD terhadapIndeks Pembangunan Manusia di ProvinsiJawa Barat“, Ekuitas: JurnalEkonomidanKeuangan Vol.4. No.3. September (2020): 285-305

Swindel, David and Kelly, Janet M (2000), Linking citizen satisfaction data to Performance Measures: a preliminary evaluation; Public Performance and Management Review, Vol. 24 No.1, pp. 30-52.

Todaro, M. P. 2000. Pembangunan Ekonomi di DuniaKetiga. EdisiKetujuh. PenerbitErlangga. Jakarta.

Undang-undang RI No. 17 Tahun 2003, tentangKeuangan Negara.

Undang-undang RI No. 18 Tahun 1965, tentangPokok-PokokPemerintah Daerah

Undang-undang RI No. 22 Tahun 1999, tentangPemerintah Daerah

Undang-undang RI No. 23 Tahun 2014, tentangPemerintah Daerah

Undang-undang RI No. 25 Tahun 2009, tentangPelayananPublik

Undang-undang RI No. 32 Tahun 2004, tentangPemerintah Daerah

Undang-undang RI No. 33 Tahun 2004, tentangPerimbanganKeuanganantaraPemerintahPusatdanPemerintah Daerah. 
Undang-undang RI No. 5 Tahun 1974, tentangPokok-PokokPemerintah Daerah

Undang-undang RI No. 5 Tahun 1979, tentangPemerintahDesa

Undang-undang RI No. 9 Tahun 2015, tentangPemerintah Daerah

Wandira, ArbieGugus (2013), Pengaruh PAD, DAU, DAK dan DBH terhadappengalokasianbelanja modal; accounting analysis journal, 2 (1) pp. 42-51.

Yusuf, M; Hartoyo, Sri; Manurung, Adler H; Temenggung, Yuswandi A, (2017), "Capital Investment Behavior of Local Government in Regional Development Bank (BPD) in Indonesia”, JurnalBinaPraja 9 (2) (2017): 281 $-293$

Yusuf, M; Hartoyo, Sri; Manurung, Adler H; Temenggung, Yuswandi A, (2017), “The Local Government Equity Participation in the Regional Development Banks in Indonesia": IOSR Journal of Economics and Finance (IOSR-JEF) Volume 8, Issue 5 Ver. II

Zeyn, Elvira (2011). Pengaruh good governance dan standard akuntansipemerintahanterhadapakuntabilitaskeuangandengankomitmenorganisasisebagaipemoderasi; Jurnalreviuakuntansidankeuangan, vol 1 No. 1, april 2011, pp 21-37 